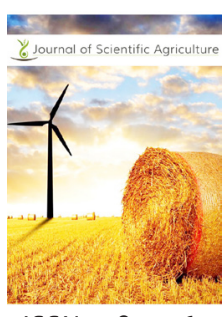

ISSN: $2184^{-0} 0261$
Received: May 08, 2020 Accepted: May 22, 2020 Published: May 27, 2020

*Corresponding Author: Suwandi Suwandi E-mail: suwandi@fp.unsri.ac.id

\section{Growth responses of oil palm seedling inoculated with Ganoderma boninense under competition with edible herbaceous plants}

\author{
Tiara Putri Rahmadhani', Suwandi Suwandi ${ }^{2,3}$, Suparman Suparman² \\ ${ }^{1}$ Crop Sciences Graduate Program, Faculty of Agriculture, Universitas Sriwijaya, Palembang, Indonesia, \\ ${ }^{2}$ Laboratory of Phytopathology, Department of Plant Pests and Diseases, Faculty of Agriculture, \\ Universitas Sriwijaya, Palembang, Indonesia - 30862, ${ }^{3}$ Food Research Center, Institute for Research and Community \\ Services, Universitas Sriwijaya, Palembang, Indonesia
}

\begin{abstract}
Basal stem rot (BSR) caused by long-term survival fungus Ganoderma boninense is the most important of oil palm disease that difficult to be controlled. Perennial herbaceous species are potentially developed for long-term BSR control and applied as mixed planting with oil palm. This research was aimed to study the competition effects of mixed planting with edible herbaceous perennial plants (edible canna (Canna indica), arrowroot (Maranta arundinacea), cocoyam (Xanthosoma sagittifolium), and water yam (Dioscorea alata) on growth of oil palm seedlings. Two competition trials (noninoculated and Ganoderma-inoculated trial) were conducted. The herbaceous plants were grown together with oil palm seedling in a polybag filled with $40 \mathrm{~L}$ field soil. Mixed planting of Ganoderma-inoculated oil palm and herbaceous plants and grown on a large soil volume resulted in a minor infection with a high variation in severity leading to insignificant effect of herbaceous competition on Ganoderma infection. Herbaceous competition significantly suppressed oil palm seedling growth under both inoculated with Ganoderma and without inoculation. Arrowroot exhibited as the most competitive herbaceous species and followed by canna and cocoyam. Water yam showed a weak competitive against oil palm seedling since only a minor interference in all observed growth characteristics.
\end{abstract}

KEYWORDS: Herbaceous competition, oil palm seedling, Ganoderma boninense, Canna indica, Maranta arundinacea, Xanthosoma sagittifolium, Dioscorea alata.

\section{INTRODUCTION}

Oil palm is the most economically important industrial crop and now cultivated for more than 14 million hectares in Indonesia. Basal stem rot (BSR) caused by wood decay fungus Ganoderma boninense Pat. is the most serious and widespread disease on oil palm plantations in Indonesia [1]. BSR causes direct economically losses on due to both direct mortality and decreasing in fresh fruit bunch yield of infected palm [2]. BSR is more prevalence as increasing of plant generations. In North Sumatra, disease prevalence of immature palm was $0,4,7$, and $11 \%$ in first, second, third and fourth generation plantings, respectively. Disease incidence of mature palm at $1 \%$ can lead to an estimated USD 38 million loss to the Indonesian economy [3]. G. boninense has long-term survival on diseased root debris in soil and infects roots of the new establishing palms during replanting [4]. Oil palm harbors abundant small roots and difficult to be fully cleaned leading to failure of disease control through common field sanitizing procedures.

Oil palm plantations in Indonesia commonly implements a standard monoculture planting procedure, although some smallholding farmers apply a mixed crops planting. There was no report about BSR infestations on the mixed crop plantations of small farmer. Potential use of mixed cropping with perennial herbaceous plants against long-term survival wood decay fungus Rigidoporus microporus has been evaluated in rubber plantation [5]. Mixed planting with herbaceous plants such as edible canna (Canna indica), arrowroot (Maranta arundinacea), and cocoyam (Xanthosoma sagittifolium), and water yam (Dioscorea alata) resulted in reduced mycelial growth and inoculum viability of $R$. microporus [6]. Silva et al. [7] demonstrated that aqueous rhizome extracts of Curcuma domestica (turmeric) and Alpinia galanga (galangale) showed an allelopathic inhibition on R. microporus both on agar and soil medium.

Copyright: $\odot$ The authors. This article is open access and licensed under the terms of the Creative Commons Attribution License (http://creativecommons.org/licenses/by/4.0/) which permits unrestricted, use, distribution and reproduction in any medium, or format for any purpose, even commercially provided the work is properly cited. Attribution - You must give appropriate credit, provide a link to the license, and indicate if changes were made. 
Edible herbaceous perennial plants are commonly grown in Indonesia for sources of starches and medicinal herbs as understory home garden plants. The plants produce rhizome and corm and undergo perennial life cycle. The plants have a robust growth and produce an extensive root system and therefore can either potentially influence survival of soil pathogens or interfere the growth of main crop. This study was aimed to determined interference competition of herbaceous plants on infection of $G$. boninense and growth of oil palm as main crop.

\section{MATERIALS AND METHODS}

\section{Competition Experiments}

Two competition trials between edible herbaceous perennial plants and oil palm seedling were conducted, viz. non-inoculated and Ganoderma-inoculated trial. Each trial consisted of mixed planting between single herbaceous plant and single oil palm seedling and the plant combinations were grown on ten polybags as replication. Single oil palm seedling was used for non-competition control. The herbaceous plants used in this study were edible canna (Canna indica), arrowroot (Maranta arundinacea), cocoyam (Xanthosoma sagittifolium), and water yam (Dioscorea alata). Rhizomes or corms of the herbaceous were collected from home gardens in South Sumatra, Indonesia. Soil collected from experimental field of Faculty of Agriculture Sriwijaya University filled to 40-L volume within $60 \times 60 \mathrm{~cm}$ black polybag $(68 \mathrm{~L})$ was used as planting medium throughout study. Sprouting rhizomes or corms with homogenous in sized and growth were selected and grown at 15-cm spaced with 3-month-old palm seedling. Polybags were arranged in green house allowing 90-cm spacing between oil palm seedling. Plant were monthly fertilized with $10 \mathrm{~g} \mathrm{NPK}$ 15-15-15 per polybag and allowed to growth for one months prior to inoculation with Ganoderma boninense. For trial with inoculation, $G$. boninense colonizing a cylindrical rubber wood block (RWB, $5 \mathrm{~cm}$ diam. $\times 5 \mathrm{~cm}$ length) incubated for 6 months was used as pathogen inoculum. Inoculation was performed by burying RWB in contact with root of oil palm in depth $15 \mathrm{~cm}$ from the soil surface.

\section{Effects on Ganoderma Infection}

Infection of $G$. boninense was measured at the end of trial (7 month after mixed planting or 6 months post-inoculation) by counting percentage number of infected main root (number of main roots showing typical necrotic symptoms / total number of main roots of individual palm $\times 100 \%$ ) and length of necrotic main root (total length of necrotic lesion of main roots / total length of main roots of individual palm $\times 100 \%$ ). Colonization of inoculated $G$. boninense on the necrotic lesion was confirmed by re-isolation of $G$. boninense from surface sterilized necrotic root on a semi-selective Ganoderma medium [8] and followed by microscopic examination. Disease symptoms were also examined for necrotic lesion on bole (swollen stem base) of oil palm by cutting the bole longitudinally at the end of trial.
Effect of herbaceous competition on wood decay activity of G. boninense was measured as decay of Ganoderma-colonized RWB. Wood decay activity of RWB was estimated based on reduction in dry weight of RWB at 6 months after inoculation relative to initial dry weight at inoculation (dry weigh of inoculated RWB / initial dry weight of RWB $\times 100 \%$ ). Initial dry weight of RWB was predicted by measuring 5 representing wood block samples after drying at $105^{\circ} \mathrm{C}$ for 24 hours.

\section{Effects on Oil Palm Growth}

Number of leaves, plant height, and stem diameter of oil palm seedling were measured at 1, 2, 4, and 7 months after mixed planting. Number and length of main roots, and fresh weight of total roots of individual palm was quantified immediately after uprooting at the end of experiment $(7$ months after mixed planting).

\section{Data Analyses}

Disease and plant growth variables between different mixed planting were analyzed using one-way analyses of variance and compared using Tukey's honestly significant test. Percentage number of infected main root and length of necrotic main root data were square root transformed to meet assumptions of normality or homogeneity of variance and data shown are untransformed means.

Analyses were applied using the packages Rcmdr and Agricolae for $\mathrm{R}$ version 3.6.2 (R Foundation for Statistical Computing).

\section{RESULTS}

\section{Effects on Ganoderma Infection}

Inoculation of G. boninense using Ganoderma-colonized RWB and grown on a large volume $(40 \mathrm{~L})$ of field soil resulted in a minor infection with a high variation in severity on roots of oil palm seedling as shown by a small portion of necrotic roots. Infection was confirmed by successful re-isolation of $G$. boninense from surface sterilized necrotic root on a semiselective Ganoderma medium and microscopic examination. Mixed planting with herbaceous plants did not significantly $(P \geq 0.05)$ affected both the percentage number of infected main root and length of necrotic main root. Mixed planting with arrowroot had a tendency to induce more Ganoderma infection as shown by a relative higher number and proportion of infected main root (Table 1). Insignificant effect was associated with a high variation between replication due to no infection on some palms for 6 months post-inoculation. BSR main symptom as either a decay of the bole (swollen stem base) or secondary leaf symptom was not developed when grown on a large volume of soil as conducted in this study. Decay activity of Ganodermacolonized RWB as assessed by reduction in dry weight was not significantly affected by mixed planting with herbaceous plant. Planting with cocoyam resulted in a slightly lower decay activity (statistically non-significant) and had similar decay of the RWB buried in soil without plant (38.9\%) (Table 1). 


\section{Effects on Oil Palm Growth}

Competition of oil palm seedling with herbaceous plants as studied in mixed planting in non-inoculated trial did not significantly affect oil palm leaf number, except for planting with canna and arrowroot that significantly had lower leaf number compared to control. In Ganoderma-inoculated trial, planting with arrowroot and cocoyam significantly reduced leaf number of oil palm at 2 and 4 months after competition, respectively. Oil palm seedlings in Ganoderma-inoculated trial produced a slightly higher number of leaves compared to that of non-inoculated trial (Table 2).

Stem diameter of oil palm seedling was negatively affected when grown in competition with herbaceous plants. In noninoculated trial, effect of herbaceous competition was evident over 7 months after mixed planting as significantly reduced stem size of oil palm in mixed planting with cocoyam. Markedly reduced in stem diameter of oil palm was shown in Ganoderma-inoculated trial. Planting with arrowroot started to reduce stem growth at 1 month after mixed planting and then continue to the end of trial. Competition with canna and cocoyam showed negative effect on stem growth by significantly reduced stem diameter at 4- and 7-months post-inoculation, respectively. Mixed planting with water

Table 1: Effect of mixed planting for 7 months with herbaceous plants on root infection by Ganoderma boninense and decay of Ganoderma-colonized rubber wood block (RWB)

\begin{tabular}{lccc}
$\begin{array}{l}\text { Competition } \\
\text { treatment }\end{array}$ & $\begin{array}{c}\text { \% number of } \\
\text { infected main root necrotic main root }\end{array}$ & $\begin{array}{c}\text { \% length of } \\
(\%)\end{array}$ \\
\hline Oil palm (control) & 18.8 & 7.1 & 47.2 \\
Edible canna+oil & 18.4 & 7.1 & 43.6 \\
palm & & & \\
Arrowroot+oil palm & 47.7 & 17.7 & 43.7 \\
Cocoyam+oil palm & 29.9 & 10.2 & 42.9 \\
Water yam+oil palm & 26.0 & 9.4 & 38.2 \\
F statistic & $1.90^{\text {ns }}$ & $1.38^{\text {ns }}$ & $1.16^{\text {ns }}$ \\
$P$ & 0.126 & 0.256 & 0.340 \\
\hline
\end{tabular}

Table 2: Effect of competition with herbaceous plants on leaf number of oil palm seedling

\begin{tabular}{lcccc}
\hline Competition treatment & \multicolumn{4}{c}{ Month after mixed planting } \\
\cline { 2 - 5 } & 1 & 2 & 4 & 7 \\
\hline Non-inoculated trial & & & & \\
Oil palm (control) & 7.2 & 7.2 & $8.7^{\mathrm{a}}$ & 10.9 \\
Edible canna+oil palm & 6.3 & 7.2 & $8.3^{\mathrm{b}}$ & 10.0 \\
Arrowroot+oil palm & 6.3 & 6.3 & $7.2^{\mathrm{b}}$ & 9.7 \\
Cocoyam+oil palm & 6.6 & 7.1 & $7.8 \mathrm{a}^{\mathrm{b}}$ & 10.4 \\
Water yam+oil palm & 6.5 & 7.3 & $8.7^{\mathrm{a}}$ & 10.7 \\
F statistic & $1.64^{\text {ns }}$ & $2.0^{\text {ns }}$ & $4.47^{*}$ & $0.95^{\text {ns }}$ \\
P & 0.179 & 0.110 & 0.039 & 0.446 \\
Ganoderma-inoculated trial & & & & \\
Oil palm (control) & 7.7 & $7.8^{\mathrm{a}}$ & $9.5^{\mathrm{a}}$ & 11.8 \\
Edible canna +oil palm & 6.9 & $7.1^{\mathrm{ab}}$ & $8.5^{\mathrm{ab}}$ & 11.0 \\
Arrowroot+oil palm & 6.5 & $6.6^{\mathrm{b}}$ & $8.2^{\mathrm{ab}}$ & 10.2 \\
Cocoyam + oil palm & 6.6 & $6.9^{\mathrm{ab}}$ & $7.9^{\mathrm{b}}$ & 10.4 \\
Water yam+oil palm & 7.4 & $7.5^{\mathrm{ab}}$ & $8.8^{\mathrm{ab}}$ & 10.9 \\
F statistic & $2.48^{\mathrm{ns}}$ & $2.97^{*}$ & $2.68^{*}$ & $2.40^{\mathrm{ns}}$ \\
P & 0.056 & 0.029 & 0.043 & 0.063 \\
\hline
\end{tabular}

yam had a non-significant effect on stem growth of the palm seedling compared to control as observed in both trials (Table 3; Figure 1). Oil palm seedlings under competition with cocoyam and water yam in Ganoderma-inoculated trial had a slightly wider stem compared to that of non-inoculated trial (Table 3).

In contrast to the negative effect of herbaceous competition on stem diameter, planting with the herbaceous did not significantly reduce height of oil palm seedling. Significant retardation of plant height was observed only on arrowroot at 7 months after mixed planting in Ganoderma-inoculated trial (Table 4, Figure 1). Oil palm seedlings under competition with cocoyam and water yam in Ganoderma-inoculated trial had a slightly higher plant height compared to that of non-inoculated trial (Table 4).

Root growth oil palm seedling as measured by number of primary roots, total length of primary root and fresh weight of total roots were severely inhibited particularly when the palms was inoculated with $G$. boninense. In competition trial without inoculation, only fresh weight of total roots was significantly interfered by the herbaceous plants. Arrowroot competition resulted in reduced the primary root number and length, but mixed planting with water yam showed non-significant effect on those variables of root growth. Competition with all herbaceous plants in both trials significantly reduced total root fresh weight of oil palm seedling. Similar to the growth responses of upperparts, root of oil palm seedlings under competition with cocoyam and water yam in Ganoderma-inoculated trial grew slightly better compared to that of non-inoculated trial (Table 5).

\section{DISCUSSION}

Mixed planting of Ganoderma-inoculated oil palm and herbaceous plants and grown on a large soil volume resulted in a minor infection with a high variation in severity

Table 3: Effect of competition with herbaceous plants on stem diameter $(\mathrm{mm})$ of oil palm seedling

\begin{tabular}{lcccc}
\hline Competition treatment & \multicolumn{4}{c}{ Month after mixed planting } \\
\cline { 2 - 5 } & 1 & 2 & 4 & 7 \\
\hline Non-inoculated trial & & & & \\
Oil palm (control) & 13 & 15 & 20 & $32^{\mathrm{a}}$ \\
Edible canna+oil palm & 10 & 14 & 18 & $26^{\mathrm{ab}}$ \\
Arrowroot+oil palm & 10 & 14 & 17 & $26^{\mathrm{ab}}$ \\
Cocoyam+oil palm & 10 & 12 & 19 & $24^{\mathrm{b}}$ \\
Water yam+oil palm & 11 & 15 & 20 & $27^{\mathrm{ab}}$ \\
F statistic & $1.40^{\mathrm{ns}}$ & $1.57^{\mathrm{ns}}$ & $1.70^{\mathrm{ns}}$ & $3.27^{*}$ \\
P & 0.240 & 0.190 & 0.150 & 0.020 \\
Ganoderma-inoculated trial & & & & \\
Oil palm (control) & $17^{\mathrm{a}}$ & $17^{\mathrm{a}}$ & $22^{\mathrm{a}}$ & $35^{\mathrm{a}}$ \\
Edible canna+oil palm & $14^{\mathrm{ab}}$ & $14^{\mathrm{ab}}$ & $19^{\mathrm{ab}} \mathrm{C}$ & $25^{\mathrm{b}}$ \\
Arrowroot+oil palm & $13^{\mathrm{b}}$ & $13^{\mathrm{b}}$ & $16 \mathrm{c}$ & $24^{\mathrm{b}}$ \\
Cocoyam+oil palm & $13^{\mathrm{ab}}$ & $14^{\mathrm{ab}}$ & $17^{\mathrm{b}} \mathrm{c}$ & $26^{\mathrm{b}}$ \\
Water yam+oil palm & $16^{\mathrm{ab}}$ & $16^{\mathrm{ab}}$ & $21^{\mathrm{ab}}$ & $29^{\mathrm{ab}}$ \\
F statistic & $3.60^{*}$ & $3.61^{*}$ & $4.51^{*}$ & $6.96^{*}$ \\
P & 0.010 & 0.008 & 0.003 & 0.0001 \\
\hline
\end{tabular}




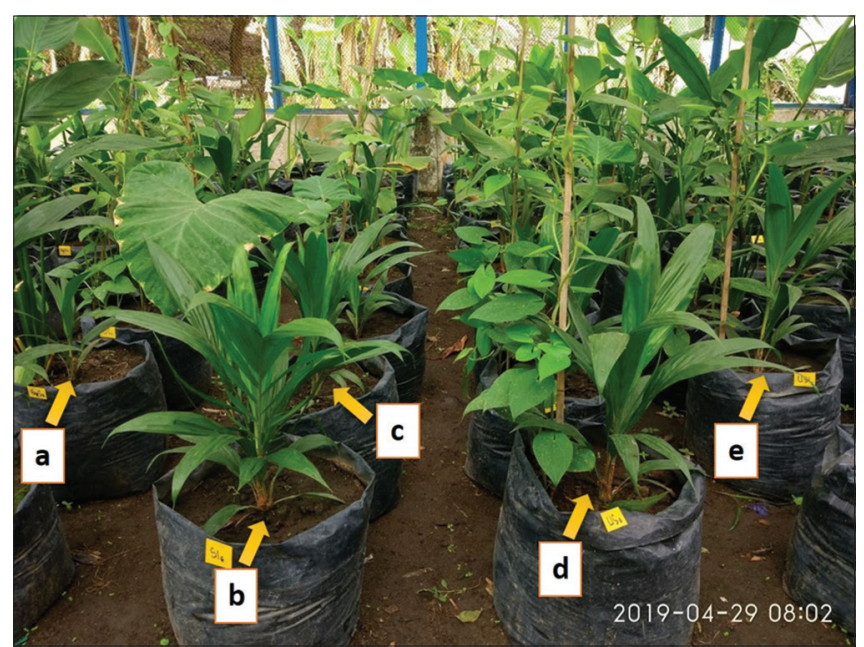

Figure 1: Growth performance of oil palm seedlings under 6-monthcompetition with herbaceous plants and inoculated for 5 months with Ganoderma boninense in greenhouse; a) growth retardation by arrowroot, b) control oil palm inoculated with $G$. boninense, c) a slight growth suppression by cocoyam, and d-e) minor growth interference by water yam.

Table 4: Effect of competition with herbaceous plants on height (cm) of oil palm seedling

\begin{tabular}{lcccc}
\hline Competition treatment & \multicolumn{4}{c}{ Month after mixed planting } \\
\cline { 2 - 5 } & 1 & 2 & 4 & 7 \\
\hline Non-inoculated trial & & & & \\
Oil palm (control) & 37 & 42 & 56 & 92 \\
Edible canna+oil palm & 39 & 44 & 57 & 85 \\
Arrowroot+oil palm & 39 & 42 & 53 & 81 \\
Cocoyam +oil palm & 34 & 39 & 48 & 71 \\
Water yam+oil palm & 39 & 44 & 56 & 89 \\
F statistic & $0.86^{\text {ns }}$ & $0.80^{\text {ns }}$ & $0.98^{\text {ns }}$ & $1.44^{\text {ns }}$ \\
$P$ & 0.49 & 0.53 & 0.43 & 0.24 \\
Ganoderma-inoculated trial & & & & \\
Oil palm (control) & 38 & 43 & 60 & $99^{\text {a }}$ \\
Edible canna+oil palm & 36 & 41 & 52 & $78^{\text {ab }}$ \\
Arrowroot+oil palm & 35 & 38 & 47 & $71^{\text {b }}$ \\
Cocoyam +oil palm & 37 & 41 & 52 & $82^{\text {ab }}$ \\
Water yam +oil palm & 42 & 48 & 60 & $92^{\text {ab }}$ \\
F statistic & $1.02^{\text {ns }}$ & $1.83^{\text {ns }}$ & $2.55^{\text {ns }}$ & $2.71^{*}$ \\
$P$ & 0.36 & 0.13 & 0.05 & 0.04 \\
\hline
\end{tabular}

Table 5: Effect of competition with herbaceous plants for 7 months on root growth of oil palm seedling

\begin{tabular}{lccc}
\hline Competition treatment & $\begin{array}{c}\text { Number of } \\
\text { primary roots }\end{array}$ & $\begin{array}{c}\text { Total length }(\mathrm{cm}) \\
\text { of primary root }\end{array}$ & $\begin{array}{c}\text { Fresh weight of } \\
\text { total roots }(\mathrm{g})\end{array}$ \\
\hline Non-inoculated trial & & & \\
Oil palm (control) & 10.7 & 453 & $35.5^{\mathrm{a}}$ \\
Edible canna+oil palm & 8.8 & 411 & $20.2^{\mathrm{b}}$ \\
Arrowroot+oil palm & 8.5 & 343 & $18.9^{\mathrm{b}}$ \\
Cocoyam+oil palm & 8.1 & 343 & $15.7^{\mathrm{b}}$ \\
Water yam+oil palm & 8.9 & 403 & $20.7^{\mathrm{b}}$ \\
F statistic & $0.90^{\text {ns }}$ & $1.05^{\text {ns }}$ & $5.27^{*}$ \\
$P$ & 0.472 & 0.391 & 0.001 \\
Ganoderma-inoculated trial & & & \\
Oil palm (control) & $12.1^{\mathrm{a}}$ & $559^{\mathrm{a}}$ & $37.9^{\mathrm{a}}$ \\
Edible canna+oil palm & $8.4^{\mathrm{ab}}$ & $360^{\mathrm{bc}}$ & $20.2^{\mathrm{b}}$ \\
Arrowroot+oil palm & $8.0^{\mathrm{b}}$ & $312^{\mathrm{c}}$ & $13.9^{\mathrm{b}}$ \\
Cocoyam+oil palm & $10.3^{\mathrm{ab}}$ & $474^{\mathrm{ab}}$ & $22.8^{\mathrm{ab}}$ \\
Water yam+oil palm & $9.7^{\mathrm{b}}$ & $433^{\mathrm{abc}}$ & $22.1^{\mathrm{b}}$ \\
F statistic & $2.62^{*}$ & $5.59^{*}$ & $5.48^{*}$ \\
$P$ & 0.048 & 0.001 & 0.001 \\
\hline
\end{tabular}

leading to insignificant effect of herbaceous competition on Ganoderma infection. G. boninense is known as a weak pathogen that need a large volume of wood to be successfully initiated an infection. RWB size used in this study was within the range of commonly used for inoculation assays $[9,10]$, except for large soil volume to accommodate mixed planting of palm and herbaceous plants. Volumetric ratio of RWB inoculum in this study was $0.28 \%$ related to soil volume. Breton et al. [9] also reported no infection on bole of oil palm over 10 months inoculation when using RWB inoculum at $0.7 \%$ soil volume. Lower volumetric inoculation ratio between inoculum and soil might result in lower inoculum potential that delay the pathogenesis. It is well known that disease progress of BSR is low, but its eventually kill the palm once infected. Diseased young palms die within 6-24 months after first symptoms, but need $2-3$ years to cause total mortality of mature palms [11].

Mixed planting with herbaceous plants either inoculated with Ganoderma or without inoculation resulted in marked growth inhibition of oil palm seedlings suggesting negative interference of herbaceous plant species. Herbaceous vegetation naturally dominates understory habitat of forest tree and is known as a major source of interference with the young woody plants [12]. Amongst the herbaceous tested, arrowroot was showed the most deleterious interference to oil palm seedling. Arrowroot started to reduce stem growth of oil palm at one month after mixed planting and then continue to the end of trial. Canna dan cocoyam also showed a negative interference on growth of oil palm seedling, but the growth inhibition was appeared over 4 months of mixed planting. Water yam was shown to have less aggressive interference to oil palm seedling as mixed planting with this climbing herbaceous resulted in non-significant growth reduction, except for fresh weight of root.

Plant interference typically refers to either competition for resources (mainly light, water and nutrients) or allelopathy [13]. Allelopathy of arrowroot was not reported, although rhizome of M. arundinacea contained 49 phytochemical compounds belong to flavonoids, alkaloids, tannins, glycosides, steroids, phenols and saponins [14]. C. indica has been reported to secrete a high concentration of organic acid that induced allelopathic effects on paddy weeds (Echinochloa crusgalli and Monocharia vaginalis) [15] and the blue-green algae Microcystis aeruginosa [16]. X. sagittifolium has known to contain a high concentration of raphides (needle-shaped calcium oxalate crystals) and cysteine protease [17], which plays defensive roles against herbivores, but not reported to act as allelochemical against other plants. Competition for water was obviously noticed during greenhouse trial, although no detailed measurement of soil water dynamics in response to mixed planting. Soil medium of mixed planting bags (polybag) were easily dried compared to wet appearance of single oil palm soil medium. The most fastest drying in soil medium was shown by mixed planting with arrowroot. Compared to other plants, arrowroot exhibited a robust growth, by actively producing new sucker every week. Among the tested herbaceous plants, formation of new shoot was normally low in water yam. It is like that herbaceous plants that actively produce new shoots are 
more competitive for water and could cause severe water leakage on oil palm seedling. Oil palm has been considered to have a high transpiration rate and the transpiration exponentially as increasing of plant age to 5-year-old [18]. Weakly competitive herbaceous plant particularly for soil water should be considered to be further studied as understory crop for BSR control research on young oil palm planting.

Mixed cropping of edible herbaceous species as understory crop of mature oil palm could benefit for food security, biodiversity and ecosystem services. Managed understory vegetations is considered to unlikely to compete for nutrients with 23-29-year-old oil palms, but even to enhance soil biodiversity and decomposition rates [19]. It has been also demonstrated that Leopard Cat habitat use was significantly increased under managed understory vegetation, with potential benefits for rat control [20]. In mature rubber plantation (7-32-year-old), mixed cropping with arrowroot, edible canna, and water yam is being practices as understory plants without any known deleterious interferences for over 7 decades [21].

\section{CONCLUSIONS}

Mixed planting of Ganoderma-inoculated oil palm and herbaceous plants and grown on a large soil volume resulted in a minor infection with a high variation in severity leading to insignificant effect of herbaceous competition on Ganoderma infection. Herbaceous competition significantly suppressed oil palm seedling growth under both inoculated with Ganoderma and without inoculation. Arrowroot exhibited as the most competitive herbaceous species and followed by canna and cocoyam. Water yam showed a weak competitive against oil palm seedling since only a minor interference in all observed growth characteristics.

\section{REFERENCES}

1. Paterson R. Ganoderma boninense disease of oil palm to significantly reduce production after 2050 in Sumatra if projected climate change occurs. Microorganisms. 2019;7:24. https://doi.org/10.3390/ microorganisms7010024

2. Roslan A, Idris AS. Economic impact of Ganoderma incidence on Malaysian oil palm plantation - A case study in Johor. Oil Palm Industry Economic Journal. 2012;12: 24-30.

3. Darmono T. Ganoderma in oil palm in Indonesia: Current status and prospective use of antibodies for the detection of infection. In: Flood J., Bridge P.D., Holderness M., editors. Ganoderma Diseases of Perennial Crops. CABI Publishing; Wallingford, UK: 2000. pp. 249-266.

4. Rees RW, Flood J, Hasan Y, Potter U, Cooper RM. Basal stem rot of oil palm (Elaeis guineensis); mode of root infection and lower stem invasion by Ganoderma boninense. Plant Pathology. 2009;58:982989. https://doi.org/10.1111/j.1365-3059.2009.02100.x

5. Situmorang A, Suryaningtyas $H$, Febbianti TR. The control of white root disease using antagonistic plant on rubber plantation. Proceedings Internasional Workshop on White Root Disease of Hevea Rubber. 2007; pp. 82-86.

6. Yulianti S, Suwandi S, Nurhayati N. Suppression ability of herbaceous plants on inoculum potential of Rigidoporus microporus. Jurnal Fitopatologi Indonesia. 2017;13:81-88. https://doi.org/10.14692/ jfi.13.3.81

7. Silva MKR, Jayasinghe CK, Tennakoon BI. Evaluation of the antagonistic effect of different plant species on white root disease causing fungus: Rigidoporus microporus. Journal of the Rubber Research Institute of Sri Lanka. 2017;94:25-32. http://doi. org/10.4038/jrrisl.v94i0.1822

8. Amanda WI, Prakoso HT 2018 Modified Ganoderma selective medium to meet Indonesia's government regulation. IOP Conference Series: Earth and Environmental Science. 2018;183:012020. https://doi. org/10.1088/1755-1315/183/1/012020

9. Breton F, Hasan Y, Hariadi S, Lubis Z, de Franqueville H. 2006. Characterization of parameters for the development of an early screening test for basal stem rot tolerance in oil palm progenies. Journal of Oil Palm Research. 2006; (Special issue, April 2006), 24-36.

10. Rees RW, Flood J, Hasan Y, Cooper RM. Effects of inoculum potential, shading and soil temperature on root infection of oil palm seedlings by the basal stem rot pathogen Ganoderma boninense. Plant Pathology 2007;56:862-870. https://doi.org/10.1111/j.13653059.2007.01621.x

11. Ariffin D, Idris AS, Singh G, 2000. Status of Ganoderma in oil palm. In: Flood J., Bridge P.D., Holderness M., editors. Ganoderma Diseases of Perennial Crops. CABI Publishing; Wallingford, UK: 2000. pp. 49-68.

12. Castro J, Leverkus A. Effect of herbaceous layer interference on the post-fire regeneration of a serotinous pine (Pinus pinaster Aiton) across two seedling ages, Forests. 2019;10(1) https://doi. org/10.3390/f10010074

13. Fernandez C, Monnier Y, Santonja M, Gallet C, Weston LA, Prévosto B, Saunier A, Baldy V, Bousquet-Mélou A. The impact of competition and allelopathy on the trade-off between plant defense and growth in two contrasting tree species. Frontiers in Plant Science. 2016;7:594. https://doi.org/10.3389/fpls.2016.00594

14. Nishaa S, Vishnupriya M, Sasikumar JM, Gopalakrishnan VK 2013. Phytochemical screening and GC-MS analysis of ethanolic extract of rhizomes of Maranta arundinacea $\mathrm{L}$. Research Journal of Pharmaceutical, Biological and Chemical Sciences. 2013;4:52-59.

15. Lin D, Sugitomo Y, Dung Y, Tsuzuki E, Matsuo E. Allelopathic effects of Canna indica on paddy weeds. Allelopathy Journal 2009;24:169-176.

16. Liu XY, Fu HY, Huang GH, Chai T, Gao PF, Wu YC. Allelopathic effect of organic acids from Canna indica on Microcystis aeruginosa. Environmental Engineering 2015;9:5769-5774.

17. Konno K, Inoue TA, Nakamura M. Synergistic defensive function of raphides and protease through the needle effect. PLoS One. 2014;9:e91341. https://doi.org/10.1371/journal.pone.0091341

18. Röll A, Niu F, Meijide A, Hardanto A, Hendrayanto, Knohl A, Hölscher D. Transpiration in an oil palm landscape: effects of palm age. Biogeosciences. 2015;12:9209-9242. https://doi.org/10.5194/ bg-12-5619-2015

19. Ashton-Butt A, Aryawan AAK, Hood ASC, Naim M, Purnomo D, Suhardi, Wahyuningsih R, Willcock S, Poppy GM, Caliman J-P, Turner EC, Foster WA, Peh KS-H, Snaddon JL. Understory vegetation in oil palm plantations benefits soil biodiversity and decomposition rates. Frontiers in Forests and Global Change. 2018;1:10. https://doi. org/10.3389/ffgc.2018.00010

20. Hood ASC, Aryawan AAK, Advento AD, Purnomo D, Wahyuningsih R, Luke SH, Ps S, Snaddon JL, Foster WA, Caliman J-P, Turner EC, Naim M. Understory vegetation in oil palm plantations promotes leopard cat activity, but does not affect rats or rat damage. Frontiers in Forests and Global Change. 2019;2:51. https://doi.org/10.3389/ ffgc.2019.00051

21. John J, Nair AM. Prospects of allelopathic research in multi-storey cropping systems. Allelopathy in Ecological Agriculture and Forestry: Proceedings of the III International Congress on Allelopathy in Ecological Agriculture and Forestry, Dharwad, India, 18-21 August 1998 (pp. 159-179). 